\title{
IMPLEMENTASI HAK PEKERJA DALAM HAL UPAH DI KANTOR NOTARIS
}

\author{
Diah Aju Wisnuwardhani \\ Fakultas Hukum Universitas Merdeka Malang \\ JI. Terusan Dieng No. 62-64; Malang; 65115; Indonesia; (0341) 580161 \\ diahajudaw@gmail.com
}

\begin{abstract}
Traffic law, almost all legal acts require legal guarantees for such actions. One of the legal guarantees is an authentic deed made by a Notary. The Notary attributively has the authority to make authentic deeds, to ratify deeds under the hand as well as to some other authorities regulated by the Notary Law. Implementation of such authority, the notary requires employees (workers) to serve and expedite services provided to the parties or clients of the notary. As workers, notary employees are entitled to wages and other rights as workers as stipulated in the Manpower Act. On the one hand, a notary public, a notary as well as an employer who is obliged to perform wages and other rights of workers as stipulated in the Manpower Act. Working relationships conducted by workers and employers are generally subordinate in nature. The position of the workers in the employment relationship, in terms of economic social is lower than the employer, for the workers need a container to reach the point kesedarajatan with employers. The most prominent civil and political rights needed by every worker is the right to peaceful assembly and assembly.
\end{abstract}

Keywords: Employer, Notary, Wage, Worker.

\begin{abstract}
Abstrak
Lalu lintas hukum, hampir semua perbuatan hukum memerlukan jaminan hukum atas perbuatan tersebut. Salah satu jaminan hukum adalah akta otentik yang dibuat oleh Notaris. Notaris secara atributif memiliki kewenangan untuk membuat akta-akta otentik, mengesahkan akta-akta di bawah tangan serta beberapa kewenangan lain yang diatur oleh Undang Undang Jabatan Notaris. Pelaksaanaan kewenangan tersebut, notaris membutuhkan karyawan (pekerja) untuk melayani dan memperlancar layanan yang diberikan kepada para pihak atau klien dari notaris tersebut. Sebagai pekerja, karyawan notaris berhak atas upah serta hak-hak lain sebagai pekerja sebagaimana diatur dalam Undang-Undang Ketenagakerjaan. Di satu sisi, notaris sebagai pejabat umum, notaris juga sebagai pemberi kerja yang berkewajiban melaksanakan pemberian upah serta hak-hak lain pekerja sebagaimana diatur dalam Undang-Undang Ketenagakerjaan. Hubungan kerja yang dilakukan oleh buruh dan majikan pada umumnya bersifat hubungan subordinasi. Kedudukan buruh di dalam hubungan kerja, ditinjau dari segi sosial ekonomis adalah lebih rendah dari majikan, untuk itu buruh memerlukan wadah untuk mencapai titik kesedarajatan dengan majikan. Hak sipil dan politik yang sangat menonjol dibutuhkan oleh setiap buruh adalah hak untuk berkumpul dan berserikat secara damai.
\end{abstract}

Kata kunci: Notaris, Pekerja, Pemberi Kerja, Upah. 
Notaris adalah pejabat umum yang secara profesi diangkat oleh Menteri Hukum dan Hak Asasi Manusia (Menkumham) dan mendapat kewenangan secara atributif berdasarkan undang-undang dan bekerja untuk kepentingan masyarakat, bangsa dan negara. Pengertian notaris sebagai profesi dan sebagai jabatan Berdasarkan Pasal 1 Ayat (1) Undang-Undang Republik Indonesia Nomor 30 Tahun 2004 tentang Jabatan Notaris (UUJN) sebagaimana telah diubah dengan UndangUndang Republik Indonesia Nomor 2 Tahun 2014 Tentang Perubahan Atas Undang Undang Jabatan Notaris (UUJN-P) adalah:

"Notaris adalah pejabat umum yang berwenang untuk membuat akta autentik dan memiliki kewenangan lainnya sebagaimana dimaksud dalam undang-undang ini atau berdasarkan undangundang lainnya."

Notaris memiliki tugas untuk melayani masyarakat dalam hal pelayanan terkait hubungan hukum yang terjadi di masyrakat. Ruang lingkup pekerjaan Notaris terikat pada peraturan jabatan dan kode etik profesi. Hal ini membuat Notaris terikat dalam satu peraturan yang berisi kaidah moral dan sanksi-sanksi terkait yang dapat dijatuhkan ketika terjadi pelanggaran. Pada Konsiderans menimbang Huruf c, UUJN-P, menyatakan bahwa:

"Notaris merupakan jabatan tertentu yang menjalankan profesi dalam pelayanan hukum kepada masyarakat". Notaris harus memahami segala ketentuan ketentuan yang terdapat dalam undangundang agar masyarakat umum masih awam dan kurang mengetahui apa itu hukum, dapat memahami dengan baik, dan tidak melakukan perbuatan yang bertentangan dengan hukum." (Andasasmita, 1983)

Notaris dalam menjalankan kewenangan dan kewajibannya tentu membutuhkan pekerja atau karyawan Notaris. Peranan karyawan Notaris pen- ting dalam hal membantu Notaris atas layanan jasa pembuatan akta, antara membantu menyiapkan pembuatan, mendaftarkan dan mengesahkan surat-surat atau akta-akta yang dibuat di bawah tangan dan menjadi saksi dalam peresmian akta (Saksi Instrumentair).

Seorang Notaris adalah pemberi kerja dimana berdasarkan Pasal 1 Angka 4 UndangUndang Republik Indonesia Nomor 13 Tahun 2003 tentang Ketenagakerjaan (selanjutnya disebut UUK), definisi pemberi kerja adalah:

“Orang perseorangan, pengusaha, badan hukum, atau badan-badan lainnya yang mempekerjakan tenaga kerja dengan membayar upah atau imbalan dalam bentuk lain."

Dalam pekerjaannya Notaris juga membutuhkan bantuan secara profesional. Dengan adanya pekerja atau karyawan, Notaris dapat melayani kebutuhan kliennya dengan cepat serta tepat pada waktunya.

Pekerja pada kantor notaris memiliki peran yang besar untuk mendukung dan menjalankan kegiatan atau pekerjaan seorang Notaris. Hubungan antara Notaris dengan pekerja merupakan hubungan hukum yang saling membutuhkan. Definisi hubungan hukum adalah terjadinya hubungan antara subjek hukum atau hubungan antara subjek hukum dengan objek hukum, dimana hubungan tersebut diatur oleh hukum serta dapat menimbulkan akibat hukum dalam bentuk hak dan kewajiban (Asyhadie, 2014). Hubungan hukum adalah hasil kreasi dari hukum selalu mempunyai dua sisi, yaitu hak dan kewajiban, dimana tidak ada hak tanpa kewajiban atau sebaliknya (Asikin, 2012).

Pasal 1 Angka 4 UUK, yang dimaksud pemberi kerja adalah: "Orang-perseorangan, pengusaha, badan hukum, atau badan lainnya yang memperkerjakan tenaga kerja dengan membayar gaji, upah atau imbalan dalam bentuk lainnya." 
Pasal 1 Angka 12 Undang-Undang Republik Indonesia Nomor 40 Tahun 2004 tentang Sistem Jaminan Sosial Nasional (UU SJSN) juncto Pasal 1 Angka 9 Undang-Undang Republik Indonesia Nomor 24 Tahun 2011 tentang Badan Penyelenggara Jaminan Sosial (UU BPJS), menyatakan pemberi kerja adalah: "Orang perseorangan, pengusaha, badan hukum, atau badan lainnya yang mempekerjakan tenaga kerja atau penyelenggara negara yang mempekerjakan pegawai negeri dengan membayar gaji, upah atau imbalan dalam bentuk lainnya." Pekerja adalah setiap orang yang bekerja dengan menerima gaji, upah, atau imbalan dalam bentuk lain. Pengertian Pekerja terdapat dalam Pasal 1 Angka 3 UUK jo. Pasal 1 Angka 11 UU SJSN jis. Pasal 1 Angka 8 UU BPJS definisi pekerja adalah: "Setiap orang yang bekerja dengan menerima gaji, upah, atau imbalan dalam bentuk lain."

Berdasarkan ketentuan-ketentuan tersebut maka hubungan Notaris dengan karyawannya adalah termasuk hubungan kerja antara pemberi kerja dan pekerja, yang menimbulkan adanya hak dan kewajiban di antara pemberi kerja dan pekerja. Pasal 1 Angka 15 UUK menyatakan: "Hubungan kerja antara pengusaha dengan pekerja dibuat berdasarkan perjanjian kerja, yang mempunyai unsur pekerjaan, upah dan perintah."

Secara sosiologis, pekerja atau karyawan memang merupakan pihak yang lebih lemah dibanding pihak pemberi kerja. Pekerja atau karyawan adalah orang yang tidak bebas dalam menentukan kehendaknya terhadap pemberi kerja, karena dalam suatu hubungan kerja pemberi kerja telah memberikan batasan-batasan yang harus diikuti oleh pihak pekerja atau karyawan, seperti yang tertera pada Peraturan Pemerintah Republik Indonesia Nomor 78 Tahun 2015 tentang Pengupahan, maka para pekerja haruslah mendapat upah yang sesuai dengan undang-undang tersebut. Upah berarti bayaran berbentuk sejumlah uang pada seseorang setelah orang terebut menyelesaikan suatu pekerjaan atau berkontribusi baik tenaga maupun pikiran sehingga suatu pekerjaan selesai (Djulmiadji, 2001).

Upah juga dapat dilihat artinya dalam rangka menunjukkan pembayaran kepada pegawai kantor, pekerja kasar atas dasar masa kerja, hasil kerja, atau standar lainnya. Upah dalam hal ini adalah gaji, komisi, uang lembur dan jasa, bonus dan sejenisnya. Sedangkan pengertian upah dalam arti lainnya adalah untuk menjelaskan pembayaran yang diberikan kepada pegawai yang bekerja secara jam-jaman dan tidak ada pengawasan terhadap pekerjaannya (Moekijat, 2001).

Menurut Imam Soepomo (1999), Upah adalah "pembayaran yang diterima pekerja atau buruh selama seseorang melakukan pekerjaan atau dipandang melakukan pekerjaan. menurut nilainya, upah dibedakan antara upah nominal, berupa uang dan upah riil, dimana dilihat dari barang yang dapat dibeli nominal uang tersebut."

\section{Kedudukan Notaris Sebagai Pemberi Kerja Menurut UUK}

Definisi notaris menurut UUJN adalah: "Pejabat umum yang berwenang untuk membuat akta otentik dan memiliki kewenangan lainnya sebagaimana dimaksud dalam undang-undang ini atau berdasarkan undang-undang lainnya."

Notaris yang merupakan pejabat umum dapat dikatakan juga sebagai pejabat publik. Di mana pejabat publik ini tidak sama dengan pejabat-pejabat publik lainnya. Notaris berwenang membuat akta otentik mengenai semua perbuatan, perjanjian dan penetapan yang diamanatkan oleh peraturan atau yang diminta dinyatakan dalam suatu akta otentik, menjamin kepastian tanggalnya, menyimpan aktanya dan memberikan grosse, salinan serta kutipannya, sepanjang pembuatan akta itu tidak ditugaskan kepada orang lain.

Notaris adalah kepanjangan tangan dari pemerintah, dimana Notaris diberi kepercayaan untuk menjalankan urusan negara, khususnya di 
bidang hukum perdata. Notaris menjawab kebutuhan masyarakat atas bantuan hukum secara netral dan berimbang agar dapat melindungi kepentingan hukum masyarakat di Indonesia. Notaris juga memberikan pelayanan hukum dan penyuluhan hukum, khususnya terkait proses pembuatan akta, hal ini bertujuan agar tercapai tujuan perlindungan hukum dan kepastian hukum, mengingat semakin meningkatnya proses pembangunan maka kebutuhan hukum masyarakat juga semakin meningkat (Santia, 2011).

Dengan wewenang Notaris yang begitu banyak dan sangat membutuhkan ketelitian maka dari itu Notaris memerlukan bantuan pekerja sehingga akta atau wewenang yang di dapat Notaris dapat sempurna dan mendapat kepastian hukum bagi para pihak yang datang ke Notaris tersebut.

Mengapa Notaris harus tunduk pada UUK, mengingat Notaris bukanlah seorang pengusaha. Hal ini yang menjadikan kenapa Notaris, bisa mengabaikan kedudukannya sebagi pemberi kerja. Hubungan kerja adalah hubungan yang terjadi antara pengusaha atau pemberi kerja dengan buruh yang mempunyai unsur pekerjaan, upah, dan perintah. Jadi karena unsur-unsur tersebut terpenuhi maka Notaris sebagai pemberi kerja memiliki hubungan kerja dengan pekerja atau karyawan sehingga Notaris harus tunduk pada undang-undang Ketenagakerjaan.

Selain sebagai pemberi kerja kategori orangperseorangan, Kantor Notaris dapat masuk dalam kategori perusahaan karena sesuai dengan yang tertera pada UUK Pasal 1 Ayat 6 mengatakan bahwa: "Perusahaan adalah:

a. Setiap bentuk usaha yang berbadan hukum atau tidak, milik orang perseorangan, milik persekutuan, atau milik badan hukum, baik milik swasta maupun milik negara yang mempekerjakan buruh/pekerja dengan membayar upah atau imbalan dengan bentuk lain.

b. Usaha-usaha sosial dan usaha-usaha lain yang mempunyai pengurus dan mempekerjakan orang lain dengan membayar upah atau imbalan dalam bentuk lain."

Pekerjaan apa yang dilakukan Notaris dapat dikatakan sebagai suatu usaha sebagaimana dimaksud UUK Pasal 1 Ayat 6 Huruf a, walaupun dalam pengertiannya Notaris telah dikatakan sebagai pejabat umum sebagai perpanjangan tangan pemerintah dalam pembuatan akta otentik dan perbuatan hukum lainnya. Usaha yang dilakukan oleh Notaris adalah usaha perseorangan atau persekutuan milik swasta yang menjalankan kewenangan pemerintah serta mempekerjakan orang lain dengan membayar upah.

Ketentuan Pasal 50 UUK mengatur tentang terjadinya hubungan kerja berdasarkan perjanjian kerja antara pengusaha dengan pekerja atau buruh. Perjanjian kerja adalah "Perjanjian antara pekerja atau buruh dengan pengusaha atau pemberi kerja yang memuat beberapa hal yaitu syarat-syarat kerja, hak dan kewajiban para pihak sementara hubungan kerja merupakan suatu hubungan antara pengusaha atau pemberi kerja dengan buruh berlandaskan perjanjian kerja dengan unsur yaitu pekerjaan, upah dan perintah." Perjanjian kerja sendiri dapat berupa perjanjian kerja lisan ataupun tertulis dimana jika perjanjian kerja tersebut berupa perjanjian lisan atau tidak tertulis maka pekerja tersebut langsung menjadi pekerja dengan waktu tidak tertentu atau pekerja tetap.

Dunia antara notaris dan pekerjanya diawali dengan hubungan hukum. Sebuah hubungan yang diatur oleh hukum dan menimbulkan akibat hukum yaitu hak dan kewajiban bagi kedua pihak yaitu notaris dan pekerja (Asyhadie \& Rahman, 2014).

Penyalahgunaan hak terjadi ketika ada orang yang menjalankan haknya tidak sesuai dengan tujuan (Soeroso, 2011). Dibutuhkan pemenuhan prestasi dari kedua belah pihak yang dapat menyebabkan keharmonisasian ataupun disharmonisasi dalam hubungan kerja. 
Hubungan kerja antara Notaris dan pekerjanya idealnya diawali dari perjanjian kerja agar jelas mengenai hak dan kewajibannya. Jika terjadi pelanggaran maka perjanjian antara para pihak dapat mengikat mereka untuk bertanggung jawab.

Unsur pekerjaan merupakan objek perjanjian sehingga menjadi faktor paling utama yang menyebabkan timbulnya perjanjian kerja. Apabila pekerjaan yang dijanjikan tidak ada, maka perjanjian kerja tersebut dikatakan batal demi hukum. Upah adalah hak pekerja yang diterima dalam bentuk uang atas pekerjaan atau jasa yang sudah selesai, sementara unsur perintah adalah hak pemberi kerja atau pengusaha yang menjadi kewajiban pekerja untuk melaksanakan pekerjaan seperti keinginan pengusaha, adalah tahapan akhir dari unsur-unsur hubungan kerja setelah unsur pekerjaan dan unsure upah (Pitoyo, 2010).

Notaris sebagai pemberi kerja dalam menjalankan usaha sangat tergantung pada pekerja agar usahanya berjalan lancar. Menurut Zainal Asikin (2010), pekerja memiliki kebutuhan dan untuk memenuhi semua kebutuhan tersebut pekerja dituntut untuk bekerja. Pemberi kerja berhak menuntut prestasi dari pekerjanya namun sebaliknya pekerja berkewajiban memenuhi tuntutan itu dengan hak untuk menuntut upah atas suatu pekerjaan (Najih \& Solmin, 2014).

Maka berdasarkan analisis hubungan UUJN dan UUK tersebut di atas Notaris dapat berkedudukan sebagai pemberi kerja baik sebagai usaha orang-perorangan, atau pengusaha milik swasta yang menjalankan kewenangan dalam bidang jasa hukum terutama pembuatan akta otentik serta mempekerjakan orang lain dan mendapatkan upah dari Notaris.

\section{Pekerja Menurut UUK}

Pada zaman kolonial buruh adalah para pekerja kasar seperti kuli, mandor, tukang dan lainlain. Khairani (2015) juga menyatakan pekerja adalah setiap orang yang melakukan pekerjaan, meskipun cakupan yang dimiliki sangat luas, misal dokter, pengacara. Istilah pegawai kemudian menjadi istilah bagi orang yang bekerja untuk dan pada pemerintah atau disebut dengan Pegawai Negeri Sipil (PNS). Hal ini diatur di dalam Undang-Undang Kepegawaian Nomor 43 tahun 1999 yang sudah diganti dengan Undang- Undang Aparatur Sipil Negara (ASN).

Pada UUK istilah pekerja dikaitkan dengan istilah buruh sehingga memiliki arti "setiap orang yang bekerja dengan menerima upah atau imbalan dalam bentuk lain", sebagaimana dinyatakan Pasal 1 Angka 3 UUK. Keterkaitan istilah buruh dan pekerja ini muncul dikarenakan dapat menggambarkan kelompok yang selalu berlawanan dengan pihak majikan. Hal ini juga yang menyebabkan adanya pergantian istilah Serikat Buruh dengan istilah Serikat Kerja (Husni, 2015).

Pada UUK selain dikenal istilah pekerja juga dikenal istilah tenaga kerja. Tenaga kerja adalah setiap orang yang mampu melakukan pekerjaan guna menghasilkan barang dan atau jasa baik untuk memenuhi kebutuhan sendiri maupun untuk memenuhi kebutuhan masyarakat. Tenaga kerja atau manpower merupakan penduduk yang berada pada kelompok usia kerja. Tenaga kerja juga diartikan sebagai pencari kerja, atau dikenal dengan istilah angkatan kerja atau labour force (Simanjuntak, 2003).

Payaman J. Simanjuntak (2003) juga menjelaskan bahwa tenaga kerja merupakan penduduk yang sudah atau sedang bekerja, yang selain mencari kerja dan melakukan aktivitas lain seperti sekolah dan mengurus rumah tangga. Mengenai hak-hak warga negara termasuk hak pekerja, baik yng menyangkut hak personal, hak legal, hak sipil dan politik secara umum diatur dalam Universal Declaration of Human Rights/ Deklarasi Universal Hak Asasi Manusia (UDHR/DUHAM). Pasal yang mengatur materi perlindungan pekerja adalah Pasal 7 bahwa "Semua orang sama di hadapan hukum; 
(equality before the law) dan berhak mendapat perlindungan hukum yang sama; (equality protection of the law)."

Hak atas pekerjaan telah digariskan dalam Pasal 23 Ayat 1 sampai 4 Universal Declaration of Human Rights/ Deklarasi Universal Hak Asasi Manusia (UDHR/ DUHAM). yang berbunyi sebagai berikut ":

1. Everyone has the rights to work, to free choice of employment, to just and fovourable condition of work and to protection against unemployment.

Setiap orang berhak atas pekerjaan, berhak dengan bebas memilih pekerjaan, berhak atas syarat-syarat perburuhan yang adil serta baik dan berhak atas perlindungan dari pengangguran.

2. Everyone, without any discrimination, has the right to equal pay for equal work

Setiap orang, tanpa diskriminasi, berhak atas pengupahan yang sama untuk pekerjaan yang sama.

3. Everyone who works has the right to just and fovourable remuneration ensuring for himself and his family an existence worthy of human dignity, and supplemented, if necessary, an existence worthy of human dignity, and supplemented, if necessary, by others means of social protection

Setiap orang yang melakukan pekerjaan berhak atas pengupahan yang adil dan baik yang menjamin kehidupannya bersama dengan keluarganya, suatu kehidupan yang pantas untuk manusia yang bermartabat, dan jika perlu ditambah dengan perlindungan sosial lainnya.

4. Everyone has the right to form and to join trade unions for the protection of his interests.

Setiap orang berhak mendirikan dan memasuki serikat-serikat pekerja untuk melindungi kepentingannya."

Hak-hak maupun kebebasan-kebebasan yang diturunkan dari hak dan kebebasan dalam pekerjaan sebagai dampak dari hubungan perburuhan. Ini mengacu kepada hak-hak seperti hak atas kondisi kerja yang adil (seperti jam kerja, pembayaran cuti tahunan, dan waktu istirahat) hak atas kondisi pekerjaan yang sehat dan nyaman, hak atas upah yang adil, dan hak atas latihan dan bimbingan kerja, serta hak-hak perempuan dan orangorang muda atas perlindungan dalam pekerjaan dan hak atas jaminan sosial dan lain-lain.

Hak-hak dalam pekerjaan dapat dinilai dari perlakuan secara adil dan tidak diskriminatif. Hal ini berdasar pada semua konvensi internasional tentang hak-hak sosial serta dalam perjanjianperjanjian khusus yang berkaitan dengan isu-isu non diskriminatif, sebagaimana termaktub beberapa undang-undang seperti Undang-Undang Republik Indonesia Nomor 80 tahun 1957, sebagai pengesahan dari konvensi ILO Nomor 100 tentang pengupahan bagi laki-laki dan perempuan untuk pekerjaan yang sama nilainya. Undang-undang Nomor 21 Tahun 1999 sebagai pengesahan dari konvensi ILO Nomor 111 mengenai diskriminasi dalam pekerjaan dan jabatan.

Pernyataan di atas menunjukkan bahwa pekerjaan merupakan aplikasi dari mandat eksistensi manusia. pekerjaan dapat dapat dipilih secara bebas. Pendapatan dari kerja harus diberikan secara baik yang memberikan pengaruh positif bagi kelangsungan hidup dan tanpa diskriminasi.

Konsep hak asasi manusia secara tegas diakui keberadaannya di dalam UUD RI Tahun 1945. Hak asasi pekerja adalah hak untuk memperoleh pekerjaan yang layak bagi sehingga merupakan hak konstitusional. Hak hak yang bukan asasi berproses sesuai kepentingan dan perkembangan masyarakat yang diatur dalam undang-undang.

Hak secara keseluruhan melekat pada setiap orang yang bekerja dalam rangka mencapai kesejahteraannya. Istilah buruh saat ini digantikan dengan istilah pekerja dengan maksud lebih menghargai dalam kaitannya dengan martabat manusia. Batasan pengertian pekerja, apabila mendasarkan 
pada ketentuan Pasal 1 Angka 3 jo Pasal 1 Angka 15 jo Pasal 1 Angka 5 jo Pasal 1 Angka 6 UndangUndang Republik Indonesia Nomor 13 Tahun 2003 tentang Ketenagakerjaan, sangat sempit dan terbatas. Hanya meliputi orang yang bekerja pada pengusaha saja, bukan pada pemberi kerja. Pengertian pemberi kerja berdasarkan ketentuan Pasal 1 angka 4 Undang-Undang Republik Indonesia Nomor 13 Tahun 2003 tentang Ketenagakerjaan adalah:

“Orang perseorangan, pengusaha, badan hukum, atau badan-badan lainnya yang mempekerjakan tenaga kerja dengan membayar upah atau imbalan dalam bentuk lain."

Pengertian tenaga kerja berdasarkan ketentuan Pasal 1 angka 2 Undang-Undang Republik Indonesia Nomor 13 Tahun 2003 tentang Ketenagakerjaan adalah:

"Setiap orang yang mampu melakukan pekerjaan guna menghasilkan barang dan/atau jasa baik untuk memenuhi kebutuhan sendiri maupun untuk masyarakat."

Pengertian pemberi kerja lebih luas dari pada pengusaha, demikian juga pengertian tenaga kerja lebih luas dari pada pekerja. Berkaitan dengan perbedaan penafsiran batasan tentang arti pekerja berdasarkan Undang-Undang Republik Indonesia Nomor 13 Tahun 2003 tentang Ketenagakerjaan seharusnya makna pekerja diartikan sebagai tenaga kerja yang mencakup pekerja informal juga, yang berhak pula atas jaminan hak asasi manusia.

Hubungan kerja yang dilakukan oleh buruh dan majikan pada umumnya bersifat hubungan subordinasi. Kedudukan buruh di dalam hubungan kerja, ditinjau dari segi sosial ekonomis adalah lebih rendah dari majikan, untuk itu buruh memerlukan wadah untuk mencapai titik kesedarajatan dengan majikan. Hak sipil dan politik yang sangat menonjol dibutuhkan oleh setiap buruh adalah hak untuk berkumpul dan berserikat secara damai.
Tujuannya untuk menyeimbangkan posisi buruh yang lemah. Dengan menggunakan hak berserikatnya yang merupakan hak kolektif, buruh dapat memperjuangkan hak- hak buruh yang terlanggar. Buruh terutama yang unskill labour kurang mempunyai posisi tawar dalam proses pembuatan klausula-klausula perjanjian kerja. Diantaranya dengan mengadakan perundingan untuk mencapai kesepakatan berkaitan dengan hak-kewajiban dan syarat-syarat kerja. Bentuk kesepakatan itu di Indonesia dituangkan dalam Perjanjian Kerja Bersama.

Bentuk perlindungan hukum bagi pekerja yang terdapat di dalam Undang-Undang Republik Indonesia Nomor 13 Tahun 2003, dibedakan antara hak tenaga kerja dengan hak pekerja atau buruh. Hak tenaga kerja adalah sebagai berikut ":

a. Setiap tenaga kerja memiliki kesempatan yang sama tanpa diskriminasi untuk memperoleh pekerjaan. (Pasal 5)

b. Setiap tenaga kerja berhak untuk memperoleh dan/ atau meningkatkan dan/atau mengembangkan kompetensi kerja sesuai dengan bakat, minat, dan kemampuannya melalui pelatihan kerja (Pasal 11).

c. Tenaga kerja berhak memperoleh pengakuan kompetensi kerja setelah mengikuti pelatihan kerja yang di selenggarakan lembaga pelatihan kerja pemerintah, lembaga pelatihan kerja swasta, atau pelatihan di tempat kerja (Pasal 18 ayat (1)).

d. Setiap tenaga kerja mempunyai hak dan kesempatan yang sama untuk memilih, mendapatkan, atau pindah pekerjaan dan memperoleh penghasilan yang layak di dalam atau di luar negeri (Pasal 31)."

Hak pekerja meliputi ":

a. Setiap pekerja/buruh berhak memperoleh perlakuan yang sama tanpa diskriminasi daripengusaha (Pasal $6)$.

b. Setiap pekerja/ buruh mempunyai hak untuk memperoleh perlindungan atas: (a) keselamatan dan kesehatan kerja; (b) moral dan kesusilaan; dan (c) perlakuan yang sesuai dengan harkat dan martabat manusia serta nilai-nilai agama. (Pasal 86). 
c. Setiap pekerja/buruh berhak memperoleh penghasilan yang memenuhi penghidupan yang layak bagi kemanusiaan (Pasal 88 ayat (1)).

d. Setiap pekerja/buruh dan keluarganya berhak untuk memperoleh jaminan sosial tenaga kerja. (Pasal 99 ayat (1)).

e. Setiap pekerja/buruh berhakmembentuk dan menjadi anggota serikat pekerja/ serikat buruh. (Pasal 104 ayat (1)).

f. Mogok kerja sebagai hak dasar pekerja/buruh dan serikat pekerja/serikat buruh dilakukan secara sah, tertib, dan damai sebagai akibat gagalnya perundingan. (Pasal 137)."

Mengenai hak atas upah pekerja atau buruh diatur dalam Pasal 88 Undang-Undang Nomor 13 Tahun 2003 tentang Ketenagakerjaan, yang mengatur sebagai berikut ":

1. Setiap pekerja/buruh berhak memperoleh penghasilan yang memenuhi penghidupan yang layak bagi kemanusiaan.

2. Untuk mewujudkan penghasilan yang memenuhi penghidupan yang layak bagi kemanusiaan sebagaimana dimaksud dalam ayat (1), pemerintah menetapkan kebijakan pengupahan yang melindungi pekerja/buruh.

3. Kebijakan pengupahan yang melindungi pekerja/ buruh sebagaimana dimaksud pada ayat (2) meliputi:

a. upah minimum;

b. upah kerja lembur;

c. upah tidak masuk kerja karena berhalangan;

d. upah tidak masuk kerja karena melakukan kegiatan lain di luar pekerjaannya;

e. upah karena menjalankan hak waktu istirahat kerjanya;

f. bentuk dan cara pembayaran upah;

g. denda dan potongan upah;

$h$. hal-hal yang dapat diperhitungkan.

4. Pemerintah menetapkan upah minimum sebagaimana dimaksud dalam Ayat (3) Hurufa berdasarkan kebutuhan hidup layak dan dengan memperhatikan produktivitas dan pertumbuhan ekonomi."

\section{Implementasi Pemenuhan Hak Pekerja Di Kantor Notaris}

Setiap pekerja memiliki hak yang sama di mata hukum termasuk pekerja notaris, haknya adalah untuk mendapatkan perlindungan saat bekerja. Perlindungan hukum merupakan perlindungan yang diberikan kepada subyek hukum dalam bentuk perangkat hukum baik preventif maupun represif, tertulis ataupun tidak.

Perlindungan hukum merupakan gambaran dari fungsi hukum, dimana hukum bertujuan keadilan, ketertiban, kepastian, kemanfaatan dan kedamaian. Perlindungan hukum adalah untuk kepentingan manusia, karena hukum dibuat oleh dan untuk manusia atau masyarakat. perlindungan hukum memiliki kaitan erat dengan fungsi hukum dan tujuan hukum. Fungsi hukum dalam hal ini juga berupa perlindungan kepentingan manusia (Nainggolan, 2011).

Dalam hal perlindungan kepentingan manusia, perlindungan hukum terhadap pekerja berbentuk pemenuhan hak dasar yang melekat dan dilindungi oleh konstitusi sebagaimana yang diatur di dalam Pasal 27 ayat (2) dan Pasal 28D Undang-Undang Dasar Republik Indonesia Tahun 1945 (selanjutnya disebut UUD) yaitu:

“Tiap-tiap warga Negara berhak atas pekerjaan dan penghidupan yang layak bagi kemanusiaan dan setiap orang berhak atas pengakuan, jaminan, perlindungan dan kepastian hukum yang adil serta perlakuan yang sama dihadapan hukum".

Pelanggaran atas yang dijamin perlindungannya oleh konstitusi adalah pelanggaran hak asasi manusia. Perlindungan terhadap tenaga kerja bertujuan menjamin hak-hak dasar pekerja dan menjamin kesetaraan serta perlakuan tanpa diskriminasi. Perlindungan hukum bagi pekerja menurut UUK termasuk perlindungan terhadap waktu dan durasi kerja, keselamatan dan kesehatan kerja, pengupahan dan kesejahteraan. 
Perlindungan waktu kerja terkait dengan durasi bekerja sehari atau seminggu, waktu istirahat dan cuti, aspek keselamatan dan kesehatan kerja adalah pengawasan keselamatan serta kesehatan mental dan fisik, perlindunganm aspek kesejahteraan terkait jaminan sosial, dan perlindungan pengupahan yang berada pada ruang lingkup kelayakan upah.

Menurut Pasal 1 angka 30 UUK menyebutkan bahwa upah adalah: "Hak pekerja/ buruh yang diterima dan dinyatakan dalam bentuk uang sebagai imbalan dari pengusaha atau pemberi kerja kepada pekerja/ buruh yang ditetapkan dan dibayarkan menurut suatu perjanjian kerja, kesepakatan, atau peraturan perundangundangan, termasuk tunjangan bagi pekerja/buruh dan keluarganya atas suatu pekerjaan dan/ atau jasa yang telah atau akan dilakukan."

Penghidupan yang layak adalah pendapatan buruh dari hasil pekerjaannya sehingga dapat memenuhi kebutuhan hidup pekerja atau buruh dan keluarga secara wajar yang meliputi sandang, pangan dan papan serta pendidikan, kesehatan, rekreasi dan jaminan hari tua. Upah adalah salah satu hak dasar pekerja atau buruh yang bersifat sensitif, karena memiliki kemungkinan munculnya perselisihan (Khakim, 2014).

Upah minimum adalah upah terendah yang terdiri atas upah pokok termasuk tunjangan tetap yang ditetapkan oleh gubernur sebagai jaring pengaman. Menurut Pasal 2 Peraturan Menteri Tenaga Kerja Nomor 7 Tahun 2013 tentang Upah Minimum, Upah Minimum terdiri dari: “a. Upah Minimum Propinsi atau Upah Minimum Kabupaten/ Kota, b. Upah Minimum Sektoral Propinsi atau Upah Minimum Sektoral Kabupaten/Kota. Dalam Peraturan Menteri Tenaga Kerja Nomor 7 Tahun 2013 tentang Upah Minimum dinyatakan bahwa: "Pengusaha dilarang membayar upah lebih rendah dari upah minimum yang telah ditetapkan" dan "Upah minimum hanya berlaku bagi pekerja/buruh yang mempunyai masa kerja kurang dari 1 (satu) tahun."

Penetapan Upah Minimum berlandaskan pada Kebutuhan Hidup Layak (KHL) dengan melihat produktivitas dan pertumbuhan ekonomi. Gubernur pada saat menetapkan UMP memperhatikan rekomendasi Dewan Pengupahan Provinsi. Gubernur dalam menetapkan UMK memperhatikan rekomendasi Dewan Pengupahan Provinsi dan rekomendasi bupati atau walikota. Pengusaha dilarang membayar upah lebih rendah dari Upah Minimum yang telah ditetapkan. Upah Minimum hanya berlaku bagi pekerja atau buruh yang mempunyai masa kerja kurang dari 1 (satu) tahun. Upah Minimum wajib dibayar bulanan kepada pekerja/ buruh. Berdasarkan kesepakatan antara pekerja/ buruh atau serikat pekerja/ serikat buruh dengan pengusaha, Upah Minimum dapat dibayarkan per minggu atau dua mingguan dengan ketentuan perhitungan Upah Minimum yang didasarkan pada upah bulanan.

Menurut Peraturan Gubernur Jawa Timur Nomor 121 Tahun 2016 Tentang Upah Minimum Kabupaten/ Kota Di Jawa Timur Tahun 2017, Upah Minimum Kota Malang pada tahun 2017 adalah

Tabel 1. Upah Kerja di Kantor Notaris

\begin{tabular}{ccccc}
\hline NOTARIS & PEKERJA & GAJI PEKERJA & $\begin{array}{c}\text { UMK } \\
\text { KOTA MALANG 2017 }\end{array}$ & KET. \\
\hline A & 1 & 2.500 .000 & & X $>$ UMK \\
& 2 & 3.250 .000 & & X $>$ UMK \\
B & 3 & 1.500 .000 & $2.272 .167,50$ & $X<\mathrm{UMK}$ \\
& 4 & 2.500 .000 & & $X>\mathrm{UMK}$ \\
C & 5 & 2.300 .000 & $X>\mathrm{UMK}$ \\
& 6 & 2.700 .000 & $X>U M K$ \\
\hline
\end{tabular}

RATA-RATA

2.458.333.33 
sebesar Rp 2.272.167,50 (dua juta dua ratus tujuh puluh dua ribu seratus enam puluh tujuh rupiah koma lima puluh sen). Nilai upah tersebut merupakan nilai upah pekerja terbesar ke-7 (tujuh) di Propinsi Jawa Timur.

Beberapa penerapan upah pekerja di Kantor Notaris di Kota Malang dapat ditunjukan oleh tabel sebagai berikut:

Berdasarkan penelusuran hukum yang dilakukan oleh penulis sebagaimana ditunjukan dalam tabel di atas, terlihat bahwa pelaksanaan pemberian upah pekerja oleh beberapa kantor notaris di Kota Malang rata-rata sebesar Rp 2.458.333.33 dimana nilai tersebut telah di atas UMK Kota Malang sebesar Rp Rp 2.272.167,50 sebagaimana diatur dalam Peraturan Gubernur Jawa Timur Nomor 121 Tahun 2016 Tentang Upah Minimum Kabupaten/ Kota Di Jawa Timur Tahun 2017. Jadi, dapat dikatakan bahwa secara rata-rata implementasi upah yang diberikan oleh Kantor Notaris/ Notaris di Kota Malang kepada karyawannya telah di atas upah minimum kabupaten atau kota sebagaimana yang ditetapkan berdasarkan Peraturan Gubernur Jawa Timur Nomor 121 Tahun 2016 Tentang Upah Minimum Kabupaten/ Kota Di Jawa Timur Tahun 2017.

\section{Simpulan}

Berdasarkan analisis hubungan pasal-pasal dalam UUJN dan UUK, Notaris dapat berkedudukan sebagai pemberi kerja baik sebagai usaha orang-perorangan, atau pengusaha milik swasta yang menjalankan kewenangan pemerintah dalam bidang jasa hukum. Implementasi pemberian upah yang diberikan oleh Kantor Notaris/ Notaris di Kota Malang kepada karyawannya telah di atas UMK sebagaimana yang ditetapkan Peraturan Gubernur Jawa Timur Nomor 121 Tahun 2016 Tentang Upah Minimum Kabupaten/ Kota Di Jawa Timur Tahun 2017.

\section{DAFTAR PUSTAKA}

Andasasmita, Komar. 1983. Notaris Selayang Pandang. Cetakan ke-2. Alumni. Bandung.

Asikin, Zainal, ddk. 2010. Dasar-Dasar Hukum Perburuhan. Raja Grafindo Persada. Jakarta.

Asikin, Zainal. 2012. Pengantar Ilmu Hukum. Raja Grafindo Persada. Jakarta.

Asyhadie, Zaeni, dkk. 2014. Pengantar Ilmu Hukum. Raja Grafindo Persada. Jakarta.

Asyhadie, Zaeni. 2007. Hukum Kerja: Hukum Ketenagakerjaan Bidang Hubungan Kerja. Raja Grafindo Persada. Jakarta.

Djulmiadji, FX. 2001. Perjanjian Kerja. Bumi Aksara, Jakarta.

Husni, Lalu. 2015. Pengantar Hukum Ketenagakerjaan. Raja Grafindo. Jakarta.

Khairani. 2015, Ringkasan Disertasi. Program Doktor Ilmu Hukum Fakultas Hukum Universitas Andalas. Padang.

Khakim, Abdul. 2014. Dasar-Dasar Hukum Ketenagakerjaan Indonesia. Citra Aditya Bakti. Bandung.

Moekijat. 2001. Dasar-dasar Motivasi. Pionir Jaya. Bandung.

Nainggolan, Bernard. 2011. Perlindungan Hukum Seimbang, Debitor, Kreditor dan Pihak-pihak yang Perkepentingan dengan Kepailitan. Alumni. Bandung.

Najih, Mokhammad \& Solmin. 2014. Pengantar Hukum Indonesia, Sejarah, Konsep Tata Hukum dan Politik Hukum Indonesia. Setara Press. Malang.

Notodisoerjono, R. Soegondo. 1993. Hukum Notariat di Indonesia Suatu Penjelasan. Raja Grafindo Persada. Jakarta.

Peraturan Gubernur Jawa Timur Nomor 121 Tahun 2016 Tentang Upah Minimum Kabupaten/ Kota Di Jawa Timur Tahun 2017. Surabaya.

Peraturan Menteri Tenaga Kerja Republik Indonesia Nomor 7 Tahun 2013 Tentang Upah Minimum. Jakarta.

Peraturan Pemerintah Republik Indonesia Nomor 78 Tahun 2015 Tentang Pengupahan. Jakarta. 
Pitoyo, Whimbo. 2010. Panduan Praktis Hukum Ketenagakerjaan. Transmedia Pustaka. Jakarta.

Santia, Dewi. 2011. Panduan Teori dan Praktik Notaris. Pustaka Yustisia. Yogyakarta.

Simanjuntak, Payaman J. 2003. Undang-Undang yang Baru Tentang Ketenagakerjaan The New Law on Manpower Act. Kantor Perburuhan Internasional. Jakarta.

Simanjuntak, Payaman J. 2011. Manajemen Hubungan Industrial. Lembaga Penerbit Fakultas Ekonomi Universitas Indonesia. Jakarta.

Soepomo, Imam. 1999. Pengantar Hukum Perburuhan. Djambatan. Jakarta.

Soeroso. R. 2011. Pengantar Ilmu Hukum. Sinar Grafika. Jakarta.

Undang-Undang Dasar Republik Indonesia Tahun 1945. Jakarta.

Undang-Undang Republik Indonesia Nomor 13 Tahun 2003 Tentang Ketenagakerjaan. Jakarta.
Undang-Undang Republik Indonesia Nomor 2 Tahun 2014 Tentang Perubahan Atas Undang Undang Jabatan Notaris. Jakarta.

Undang-Undang Republik Indonesia Nomor 24 Tahun 2011 tentang Badan Penyelenggara Jaminan Sosial. Jakarta.

Undang-Undang Republik Indonesia Nomor 40 Tahun 2004 tentang Sistem Jaminan Sosial Nasional. Jakarta.

Universal Declaration of Human Rights/ Deklarasi Universal Hak Asasi Manusia (UDHR/ DUHAM).

\section{How to Cite:}

Wisnuwardhani, Diah Aju. 2017. Implementasi Hak Pekerja dalam Hal Upah Di Kantor Notaris. Jurnal Cakrawala Hukum. 8 (1): 33-43. 